\title{
Sewage Sludge Amendment Combined with Green Manuring to a Coastal Mudflat Salt-Soil in Eastern China: Effects on Soil Physicochemical Properties and Maize Yield
}

\author{
Yanchao Bai, ${ }^{1,2}$ Wengang Zuo, ${ }^{3}$ Yiyun Yan, ${ }^{1}$ Chuanhui Gu, ${ }^{4}$ Yongxiang Guan, ${ }^{5}$ \\ Lijuan Mei, ${ }^{1}$ Weijie Xue, ${ }^{1}$ Yuhua Shan, ${ }^{1,2}$ and Ke Feng ${ }^{1,2}$ \\ ${ }^{1}$ College of Environmental Science and Engineering, Yangzhou University, Yangzhou 225127, China \\ ${ }^{2}$ Jiangsu Collaborative Innovation Center for Solid Organic Waste Resource Utilization, Nanjing 210095, China \\ ${ }^{3}$ College of Agriculture, Yangzhou University, Yangzhou 225127, China \\ ${ }^{4}$ Department of Geological and Environmental Sciences, Appalachian State University, Boone, NC 28607, USA \\ ${ }^{5}$ Jiangsu Cultivated Land Quality and Agro-Environment Protection Station, Nanjing 210036, China
}

Correspondence should be addressed to Yanchao Bai; byc529@gmail.com and Yuhua Shan; shanyuhua@outlook.com

Received 21 February 2017; Accepted 10 August 2017; Published 28 September 2017

Academic Editor: David Clay

Copyright (C) 2017 Yanchao Bai et al. This is an open access article distributed under the Creative Commons Attribution License, which permits unrestricted use, distribution, and reproduction in any medium, provided the original work is properly cited.

\begin{abstract}
Sewage sludge and green manure have become widely used organic amendments to croplands in many regions of the world. However, the amending effect of the combination of sewage sludge with green manuring in reclaimed coastal mudflat salt-soil has been unclear yet. This paper was one of earlier studies to investigate and evaluate the effects of sewage sludge amendment combined with green manuring on selected soil physicochemical properties of the mudflat soil in a rain-fed agroecosystem. The mudflat salt-soil was amended by one-time input of sewage sludge at the rates of $0,30,75,150$, and $300 \mathrm{tha}^{-1}$. After green manuring for three consecutive seasons, maize (Zea mays L.) was planted in 2013 and 2014. The results showed that SSA combined with green manuring decreased bulk density, $\mathrm{pH}$, salinity, and exchangeable sodium percentage of the topsoil (0-20 cm soil layer) and increased aggregate stability, cation exchange capacity, and $\mathrm{N}$ and $\mathrm{P}$ concentration of the topsoil. As a result, the maize yield increased with the increase of SSA rates. Sewage sludge combined with green manuring can be applied in coastal mudflat salt-soil amendment, which provides an innovative way to create arable land resources and safe disposal of sewage sludge.
\end{abstract}

\section{Introduction}

Soil salinity is a major obstacle in the potential utilization of land resources in salt-affected areas. Salt-affected soils are found in many parts of the world, and about $20 \%$ of the world's cultivated land is salt-affected [1]. In the east of China, there were approximately $1.1 \sim 1.2$ million ha saltsoil reclaimed from coastal mudflats in the past five decades $[2,3]$. It is estimated that additional $2000 \mathrm{~km}^{2}$ mudflats along the Jiangsu coast will be reclaimed by 2020 , and another reclamation of $4400 \mathrm{~km}^{2}$ mudflats located in the Yellow River Delta is under evaluation [4]. The newly reclaimed coastal mudflats, as typical salt-soil, have high salinity, high $\mathrm{pH}$, and macronutrient deficiencies [5]. High salinity of mudflat salt-soil is driven by the strong evaporation demand of the air, shallow salt solution rise to the soil surface through soil capillary in the dry season [6]. In the area rich in freshwater resources, soil salinity reduction is often accomplished through freshwater irrigation [7]. However, faced with the scarcity of freshwater resources, organic matter amendment is an effective alternative to decrease soil salinity by forming soil aggregates and breaking capillary rise in saltsoil reclaimed from coastal mudflats in the eastern area of China $[8,9]$.

Salt-soil generally exhibits poor aggregates due to low organic matter content. Previous studies indicated that soil aggregates can be improved by the application of organic materials such as poultry manures, green manures, and compost [10-13]. Barzegar et al. [14] found that the addition of plant residues to a salt-soil had a positive influence on the 
stability of soil aggregates and decreased the soil salinity and exchangeable sodium percentage (ESP).

Sewage sludge generated in municipal wastewater treatment plants has caused serious environmental pollution and ecological safety concern. Safe disposal of sewage sludge is a challenge in China. Approximately 78.4 billion metric tons of sewage sludge was derived from more than 2600 wastewater treatment plants in China in 2015 [15]. Agricultural application of sewage sludge is an effective waste disposal and soil amendment technique that can improve the chemical, physical, and biological characteristics of soils [16-19]. Sewage sludge is rich in organic matter and other nutrients and can be used for mudflat salt-soil amendment $[9,20,21]$.

However, the quality and application rate of sewage sludge must be controlled, because it might bring various pollutants such as heavy metals, pathogens, and organic micropollutants into the environment and subsequently into the food chain $[22,23]$. Thus, total amount of sewage sludge applied must be controlled in compliance with the China national standard for agricultural use of sewage sludge $(\mathrm{GB} / \mathrm{T}$ 24600-2009) and on the premise of total amount of toxins elements from sewage sludge. Green manuring, on the other hands, plays an important role in soil quality and sustainability of agricultural systems and can be used as an alternative to sewage sludge to increase organic carbon to the soil [24]. Soil water-stable aggregates stability and soil organic matter can be improved by green manuring [25]. Green manuring was potential source for organic matter and nutrient $[26,27]$ and may provide economic and biological advantages over the traditional approach of soil incorporation [28]. Zubair et al. [29] found that green manuring in salt-affected soil increased soil organomineral interactions. Bruning et al. [30] also found the use of green manure can potentially increase crop productivity in a salt-affected soil and thus contribute to the sustainability of saline agricultural systems. Green manuring in mudflat salt-soil can be an effective way to minimize input of sewage sludge as the source of toxins elements.

The past research mainly focused on the application of sewage sludge or green manuring in farmlands [31-34]. However, the application of sewage sludge combined with green manuring to amend mudflat salt-soils has received no attention. The impacts of applying sewage sludge alone to reclaimed mudflat soil on fertility development, growth of ryegrass, Sesbania, and maize and on heavy metals behaviors including their accumulation and fraction in soil and uptake by plants were investigated and evaluated in our previous studies $[9,20,21,35]$. This study was one of pioneering studies to investigate and evaluate the sustaining effects of sewage sludge amendment combined with green manuring on the soil aggregates, organic carbon, salinity, $\mathrm{pH}$, and $\mathrm{N}$ and $\mathrm{P}$ of mudflat salt-soil, as well as yield of maize (Zea mays L.) in mudflats salt-soil in a rain-fed agroecosystem.

\section{Materials and Methods}

2.1. Study Area and Experimental Materials. The experiment site was located in the Senmao Farm (E 121 $23^{\prime} 23^{\prime \prime}, \mathrm{N}$ $32^{\circ} 20^{\prime} 03^{\prime \prime}$ ) of the Rudong County, Jiangsu Province, China. The land, as reclaimed from coastal mudflats in 2007, has
TABLE 1: Basic chemical properties of the coastal mudflat salt-soil and sewage sludge used in this study.

\begin{tabular}{lcc}
\hline Items & Mudflat soil & Sewage sludge \\
\hline $\mathrm{pH}$ & 9.02 & 6.32 \\
Salinity (\%o) & 8.51 & 32.9 \\
Organic carbon $\left(\mathrm{g} \mathrm{kg}^{-1}\right)$ & 1.97 & 216.2 \\
Total N $\left(\mathrm{N} \mathrm{g} \mathrm{kg}^{-1}\right)$ & 0.282 & 51.2 \\
Total P $\left(\mathrm{P} \mathrm{g} \mathrm{kg}^{-1}\right)$ & 0.507 & 5.51 \\
Alkaline N $\left(\mathrm{N} \mathrm{mg} \mathrm{kg}^{-1}\right)$ & 17.08 & 3440 \\
Available P $\left(\mathrm{P} \mathrm{mg} \mathrm{kg}^{-1}\right)$ & 6.99 & 813 \\
\hline
\end{tabular}

been under amendment since 2011. The distance from the site to the Yellow Sea coastline is approximately $1.2 \mathrm{~km}$. The predominant soil is silt loam and is typic salt-affected soil.

The experiment region is characterized by subtropic humid monsoon climate with distinct seasons. Mean annual rainfall is $1041.1 \mathrm{~mm}$ with approximately $61 \%$ of annual rainfall occurring between June and August (from 2011 to 2014). Mean annual temperature is $15.7^{\circ} \mathrm{C}$ with an average 230.5 frost-free days and average sunshine duration of $5.2 \mathrm{~h} \mathrm{~d}^{-1}$. The cold, dry season is from October to March and the hot, wet season is between April and September.

The experimental sewage sludge was collected from Sewage Treatment Plant of Rudong County in September, 2011. The quality of the sludge complied with the China national standard for agricultural use of sewage sludge (GB/T 24600-2009). Some chemical properties of mudflat saltaffected soil and sewage sludge were shown in Table 1.

2.2. Experimental Design. The field experiment was conducted in randomized complete block design (RCB) with each plot of $4 \mathrm{~m}$ length and $4 \mathrm{~m}$ width. The organic carbon content in farm soil in this region was about $0.5 \%-3.0 \%$ of total soil weight. Therefore, $30,75,150$, and $300 \mathrm{tha}^{-1}$ (metric tons per hectare) (about $0.5 \%, 0.9 \%, 1.6 \%$, and $2.9 \%$ organic carbon of soil weight in the $0-20 \mathrm{~cm}$ soil layer, resp.) sewage sludge amendment (SSA) rates on a dried weight basis by one-time application were used. The soil without sludge amendment was the control soil. The plots were repeated three times. On experimental site, the sewage sludge was mixed uniformly with the soil of $20 \mathrm{~cm}$ layer by a rototiller in late October 2011. Ryegrass (Lolium perenne L.) and Sesbania (Sesbania cannabina) were adopted as green manures due to their high-quality and salt-tolerance and successively planted and tilled from October 2011 to September 2012. The rain-fed ryegrass-maize rotation was carried out from October 2012 to September 2014. Maize (Zea mays L.) as a typical dryland and salt-susceptible crop was cultivated as a test crop. Maize was sowed two seeds per hole with average row spacing of $0.50 \mathrm{~m}$ and plant spacing of $0.25 \mathrm{~m}$ in early July 2013 and 2014 and harvested in late September 2013 and 2014. Thinning of maize seedlings was performed 20 days after sowing (DAS), leaving one seedling per hole. Weeds were hand-hoed two times at 20 and 48 DAS, respectively. During the experimental period, all plants were rain-fed, and no extra artificial irrigation was carried out. 
2.3. Soil Analysis. Soil samples from each plot at depths of $0-20$ and $20-40 \mathrm{~cm}$ were collected in quadruplicate in late September 2013 and 2014 at maize harvest stage. The soil samples were immediately transported to the laboratory. Soil bulk density was measured by the core method. Soil salinity was measured by the gravimetric method [36]. The size composition of soil water-stable aggregates was analyzed by wet-sieving method using soil aggregate analyzer (DIK-2001, Daiki, Japan). The $\mathrm{K}_{2} \mathrm{Cr}_{2} \mathrm{O}_{7}$ method was used for analysis of soil organic carbon. The $\mathrm{pH}$ of soil was measured in suspension of 1:5 (weight/volume) by $\mathrm{pH}$ meter (Model IQ150, Spectrum, USA). Alkaline $\mathrm{N}$ and available $\mathrm{P}$ were determined by alkaline hydrolysis diffusion and sodium bicarbonate $\left(\mathrm{NaHCO}_{3}\right)$ extraction method, respectively. The cation exchange capacity (CEC) of soil was measured by using the ammonium acetate $\left(\mathrm{NH}_{4} \mathrm{OAc}\right)$ method after successively leached in sodium acetate $(\mathrm{NaOAc})$ solution and alcohol. Exchangeable sodium content was analyzed to calculate exchangeable sodium percentage (ESP) and was extracted with ammonium acetate-ammonium hydroxide $\left(\mathrm{NH}_{4} \mathrm{OAc}\right.$ $\left.\mathrm{NH}_{4} \mathrm{OH}\right)(\mathrm{pH} 9)$ and measured by a flame spectrophotometer [36]. The all methods and procedures for soil chemical properties involved in this study were described in detail by the Soil and Agro-Chemistry Analysis [36].

2.4. Plant Analysis. Ten maize plants were sampled randomly from each plot for estimation of aerial part growth at their respective harvest seasons in late September 2013 and 2014. Maize grains were threshed using a miniature thresher for each replica, and yields of maize were determined by weighing the grains after dried at $105^{\circ} \mathrm{C}$ for 15 minutes and oven-dried at $80^{\circ} \mathrm{C}$ until constant weight was achieved.

2.5. Statistical Analysis. Analysis of variance (ANOVA) for the data obtained was conducted using SPSS 13.0 software (SPSS Inc., USA) with the model of RCB design. The differences between the treatments were detected by the least significant difference (LSD) method at the 0.05 level.

\section{Results}

3.1. Size Composition of Soil Water-Stable Aggregates and Bulk Density. Table 2 presents the test results of the waterstable aggregates size composition in the soil samples collected in September 2013 and 2014. Under the influence of different sewage sludge amendment combined with green manuring, the percentage of aggregates of different size classes significantly varied in the topsoil $(0-20 \mathrm{~cm})$ and subsurface $(20-40 \mathrm{~cm})$ layers. The percentage of $>0.25 \mathrm{~mm}$ and $0.106-0.25 \mathrm{~mm}$ water-stable aggregates in the topsoil increased with increasing SSA rates, whereas no significant changes $(p>0.05)$ were found in the percentage of waterstable aggregates of the subsurface soil. The percentage of $>0.25 \mathrm{~mm}$ water-stable aggregates in the topsoil increased by $7.5-25.1 \%, 29.7-96.1 \%, 105.5-121.6 \%$, and $143.5-247.7 \%$ at 30 , 75,150 , and 300 tha $^{-1}$ SSA rates in 2013 and 2014, respectively, compared to the control soil. There were sharp increases in the percentage of $>0.25 \mathrm{~mm}$ water-stable aggregates in the

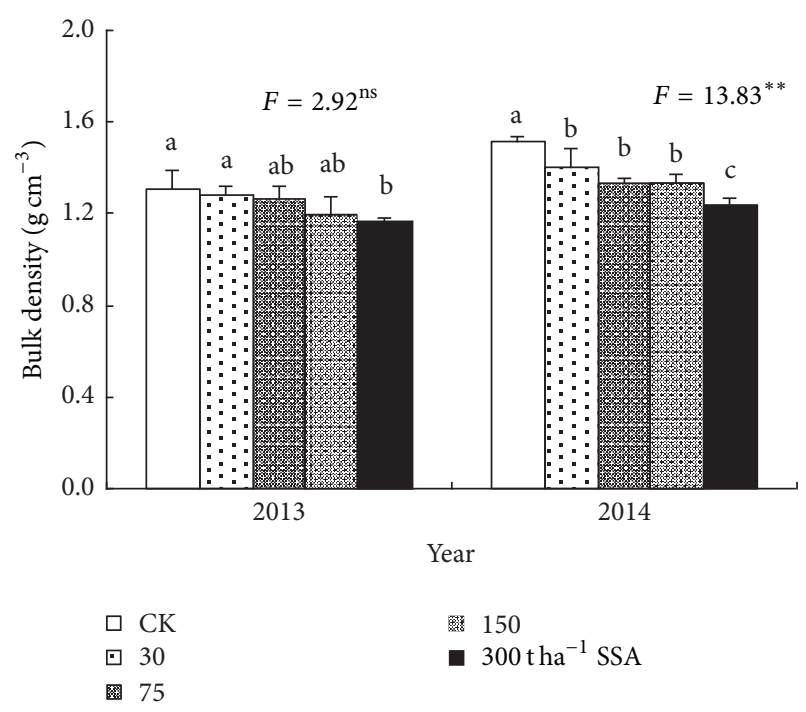

FIGURE 1: Effects of sewage sludge amendment (SSA) combined with green manuring on bulk density of coastal mudflat salt-soil. Vertical bars indicate standard deviations of the means. Columns with different letters show significant difference between sewage sludge amendment rates at $p<0.05$ by LSD's multiple range test. Values of $F$ are the $F$ test in ANOVA; ${ }^{* *} p<0.01 ;{ }^{\text {ns }} p>0.05$.

topsoil at all SSA rates in September 2014, compared to those in 2013 .

The sewage sludge amendment combined with green manuring significantly decreased bulk density in the salt-soil, and soil bulk density decreased with increasing SSA rates (Figure 1). The similar trend was found in 2013 and 2014. The soil bulk density decreased by $7.4 \%, 12.2 \%, 12.3 \%$, and $18.5 \%$ at $30,75,150$, and $300 \mathrm{tha}^{-1}$ SSA rates in 2014, respectively, compared to the control soil.

3.2. Soil Salinity, $p H$, and ESP. As shown in Table 3, the SSA combined with green manuring significantly decreased salinity of the topsoil, whereas no significant changes $(p>$ 0.05 ) were found in salinity of the subsurface soil. The salinity of topsoil decreased by $26.5-37.9 \%, 29.9-59.8 \%, 44.7-66.6 \%$, and $56.7-73.1 \%$ at $30,75,150$, and $300 \mathrm{tha}^{-1}$ SSA rates in 2013 and 2014, respectively, compared to the control soil.

The sewage sludge amendment combined with green manuring significantly decreased $\mathrm{pH}$ in coastal mudflat saltsoil, and $\mathrm{pH}$ decreased with increasing SSA rates in 2013 and 2014 (Figure 2(a)). The $\mathrm{pH}$ decreased by $0.32-0.47,0.38-0.79$, $0.63-1.29$, and $1.13-1.65 \mathrm{pH}$-unit at $30,75,150$, and $300 \mathrm{tha}^{-1}$ SSA rates in 2013 and 2014, respectively, compared to the control soil. The ESP in mudflat salt-soil also decreased with increasing SSA rates in 2013 and 2014 (Figure 2(b)). The ESP decreased by $14.0-22.7 \%, 32.0-38.7 \%, 43.2-54.0 \%$, and $60.2-69.8 \%$ at $30,75,150$, and $300 \mathrm{tha}^{-1}$ SSA rates in 2013 and 2014, respectively, compared to the control soil.

3.3. Soil OC, CEC, and Nutrient Content. As shown in Figure 3(a), the sewage sludge amendment combined with 
TABLE 2: Effects of sewage sludge amendment (SSA) combined with green manuring on the size composition of soil water-stable aggregates at $0-20 \mathrm{~cm}$ and $20-40 \mathrm{~cm}$ depths of coastal mudflat salt-soil.

\begin{tabular}{|c|c|c|c|c|c|c|c|}
\hline \multirow{3}{*}{ Year } & \multirow{3}{*}{ SSA $\left(\right.$ tha $\left.^{-1}\right)$} & \multicolumn{6}{|c|}{ Water-stable aggregates (\%) } \\
\hline & & \multicolumn{3}{|c|}{$0-20 \mathrm{~cm}$ depth } & \multicolumn{3}{|c|}{$20-40 \mathrm{~cm}$ depth } \\
\hline & & $>0.25 \mathrm{~mm}$ & $0.106-0.25 \mathrm{~mm}$ & $<0.106 \mathrm{~mm}$ & $>0.25 \mathrm{~mm}$ & $0.106-0.25 \mathrm{~mm}$ & $<0.106 \mathrm{~mm}$ \\
\hline \multirow{6}{*}{2013} & 0 & $3.33 \pm 1.42^{\mathrm{c}}$ & $0.98 \pm 0.16^{\mathrm{b}}$ & $95.71 \pm 1.92^{\mathrm{a}}$ & $0.61 \pm 0.35^{\mathrm{a}}$ & $0.59 \pm 0.06^{\mathrm{a}}$ & $98.80 \pm 0.29^{\mathrm{a}}$ \\
\hline & 30 & $3.58 \pm 1.50^{\mathrm{bc}}$ & $1.33 \pm 0.60^{\mathrm{b}}$ & $95.11 \pm 3.09^{\mathrm{a}}$ & $2.98 \pm 2.81^{\mathrm{a}}$ & $0.77 \pm 0.32^{\mathrm{a}}$ & $96.25 \pm 3.13^{\mathrm{a}}$ \\
\hline & 75 & $4.32 \pm 2.35^{\mathrm{bc}}$ & $1.09 \pm 0.45^{\mathrm{b}}$ & $94.60 \pm 2.80^{\mathrm{a}}$ & $1.02 \pm 0.61^{\mathrm{a}}$ & $0.52 \pm 0.03^{\mathrm{a}}$ & $98.46 \pm 0.58^{\mathrm{a}}$ \\
\hline & 150 & $7.38 \pm 2.58^{\mathrm{b}}$ & $1.75 \pm 0.47^{\mathrm{b}}$ & $90.87 \pm 3.04^{\mathrm{ab}}$ & $2.31 \pm 0.96^{\mathrm{a}}$ & $0.81 \pm 0.19^{\mathrm{a}}$ & $96.88 \pm 1.15^{\mathrm{a}}$ \\
\hline & 300 & $11.58 \pm 2.69^{\mathrm{a}}$ & $2.97 \pm 0.98^{\mathrm{a}}$ & $85.46 \pm 4.17^{\mathrm{b}}$ & $1.20 \pm 0.10^{\mathrm{a}}$ & $0.50 \pm 0.06^{\mathrm{a}}$ & $98.30 \pm 0.16^{\mathrm{a}}$ \\
\hline & $F$-value & $7.77^{* *}$ & $5.59^{*}$ & $5.80^{*}$ & $1.44^{\mathrm{ns}}$ & $1.07^{\mathrm{ns}}$ & $1.05^{\mathrm{ns}}$ \\
\hline \multirow{6}{*}{2014} & 0 & $13.00 \pm 2.17^{\mathrm{b}}$ & $3.18 \pm 0.95^{\mathrm{b}}$ & $83.83 \pm 1.46^{\mathrm{a}}$ & $0.99 \pm 0.19^{\mathrm{a}}$ & $0.50 \pm 0.06^{\mathrm{a}}$ & $98.51 \pm 0.13^{\mathrm{a}}$ \\
\hline & 30 & $16.26 \pm 7.23^{\mathrm{b}}$ & $3.41 \pm 0.38^{\mathrm{b}}$ & $80.34 \pm 7.57^{\mathrm{ab}}$ & $0.68 \pm 0.45^{\mathrm{a}}$ & $0.59 \pm 0.06^{\mathrm{a}}$ & $98.73 \pm 0.38^{\mathrm{a}}$ \\
\hline & 75 & $25.49 \pm 7.58^{\mathrm{a}}$ & $5.11 \pm 2.08^{\mathrm{ab}}$ & $69.40 \pm 9.62^{b c}$ & $1.97 \pm 1.95^{\mathrm{a}}$ & $0.77 \pm 0.32^{\mathrm{a}}$ & $97.26 \pm 2.27^{\mathrm{a}}$ \\
\hline & 150 & $26.72 \pm 2.43^{\mathrm{a}}$ & $5.12 \pm 0.46^{\mathrm{ab}}$ & $68.16 \pm 2.41^{c}$ & $2.22 \pm 1.09^{\mathrm{a}}$ & $0.72 \pm 0.32^{\mathrm{a}}$ & $97.06 \pm 1.41^{\mathrm{a}}$ \\
\hline & 300 & $31.65 \pm 2.93^{\mathrm{a}}$ & $6.84 \pm 4.45^{\mathrm{a}}$ & $61.51 \pm 7.27^{\mathrm{c}}$ & $1.45 \pm 0.26^{\mathrm{a}}$ & $0.61 \pm 0.10^{\mathrm{a}}$ & $97.94 \pm 0.35^{\mathrm{a}}$ \\
\hline & $F$-value & $6.98^{* *}$ & $5.72^{*}$ & $6.04^{* *}$ & $0.78^{\mathrm{ns}}$ & $0.541^{\mathrm{ns}}$ & $0.73^{\text {ns }}$ \\
\hline
\end{tabular}

Values are mean \pm SD of three replicates. Different letters in each column indicate significant difference at $p<0.05$ by LSD's multiple range test. Values of $F$ are the $F$ test in ANOVA; ${ }^{*} p<0.05 ;{ }^{* *} p<0.01 ;{ }^{\text {ns }} p>0.05$.

TABLE 3: Effects of sewage sludge amendment (SSA) combined with green manuring on salinity of coastal mudflat salt-soil.

\begin{tabular}{|c|c|c|c|}
\hline \multirow{2}{*}{ Year } & \multirow{2}{*}{ SSA $\left(\mathrm{tha}^{-1}\right)$} & \multicolumn{2}{|c|}{ Salinity (\%o) } \\
\hline & & $0-20 \mathrm{~cm}$ depth & $20-40 \mathrm{~cm}$ depth \\
\hline \multirow{6}{*}{2013} & 0 & $7.67 \pm 0.11^{\mathrm{a}}$ & $9.40 \pm 0.57^{\mathrm{a}}$ \\
\hline & 30 & $4.76 \pm 0.15^{\mathrm{b}}$ & $8.38 \pm 1.01^{\mathrm{a}}$ \\
\hline & 75 & $3.08 \pm 0.05^{\mathrm{c}}$ & $8.48 \pm 1.06^{\mathrm{a}}$ \\
\hline & 150 & $2.56 \pm 0.25^{\mathrm{d}}$ & $8.25 \pm 1.30^{\mathrm{a}}$ \\
\hline & 300 & $2.06 \pm 0.24^{\mathrm{e}}$ & $7.97 \pm 0.82^{\mathrm{a}}$ \\
\hline & $F$-value & $491.75^{* *}$ & $0.90^{\mathrm{ns}}$ \\
\hline \multirow{6}{*}{2014} & 0 & $6.33 \pm 2.13^{\mathrm{a}}$ & $9.34 \pm 0.27^{\mathrm{a}}$ \\
\hline & 30 & $4.65 \pm 0.63^{\mathrm{b}}$ & $8.14 \pm 0.63^{\mathrm{a}}$ \\
\hline & 75 & $4.44 \pm 0.07^{\mathrm{bc}}$ & $8.57 \pm 1.25^{\mathrm{a}}$ \\
\hline & 150 & $3.50 \pm 0.66^{\mathrm{cd}}$ & $8.27 \pm 1.27^{\mathrm{a}}$ \\
\hline & 300 & $2.74 \pm 0.82^{\mathrm{d}}$ & $7.75 \pm 0.51^{\mathrm{a}}$ \\
\hline & $F$-value & $17.96^{* *}$ & $1.37^{\mathrm{ns}}$ \\
\hline
\end{tabular}

Values are mean \pm SD of three replicates. Different letters in each column indicate significant difference at $p<0.05$ by LSD's multiple range test. Values of $F$ are the $F$ test in ANOVA; ${ }^{*} p<0.05 ;{ }^{* *} p<0.01 ;{ }^{\text {ns }} p>0.05$.

green manuring significantly increased OC content in mudflat salt-soil, and the OC content increased with increasing SSA rates in 2013 and 2014. The SSA combined with green manuring increased OC concentration by $97.5-122.2 \%$, $167.9-205.7 \%, 320.2-345.2 \%$, and $352.8-427.8 \%$ at $30,75,150$, and $300 \mathrm{tha}^{-1}$ SSA rates in 2013 and 2014, respectively, compared with the control soil. The sewage sludge amendment combined with green manuring significantly increased CEC in mudflat salt-soil, and CEC increased with increasing SSA rates in 2013 and 2014 (Figure 3(b)). The CEC increased by $1.1-15.0 \%, 17.0-38.9 \%, 46.3-50.7 \%$, and $65.6-76.4 \%$ at 30,75 ,
150, and 300 tha $^{-1}$ SSA rates in 2013 and 2014, respectively, compared to the control soil.

The sewage sludge amendment combined with green manuring significantly increased total $\mathrm{N}$ and $\mathrm{P}$, alkaline $\mathrm{N}$, and available $\mathrm{P}$ in mudflat salt-soil (Figure 4). The concentrations of total $\mathrm{N}$ and $\mathrm{P}$, alkaline $\mathrm{N}$, and available $\mathrm{P}$ in mudflat salt-soil increased with increasing SSA rates, and the similar trend was found in 2013 and 2014. The total $\mathrm{N}$ and $\mathrm{P}$ increased by $18.0 \%, 129.0 \%, 193.0 \%$, and $311.0 \%$ and $62.7 \%$, $71.2 \%, 232.2 \%$, and $291.7 \%$ at $30,75,150$, and $300 \mathrm{t} \mathrm{ha}^{-1}$ SSA rates in 2014, respectively, compared to the control soil. 


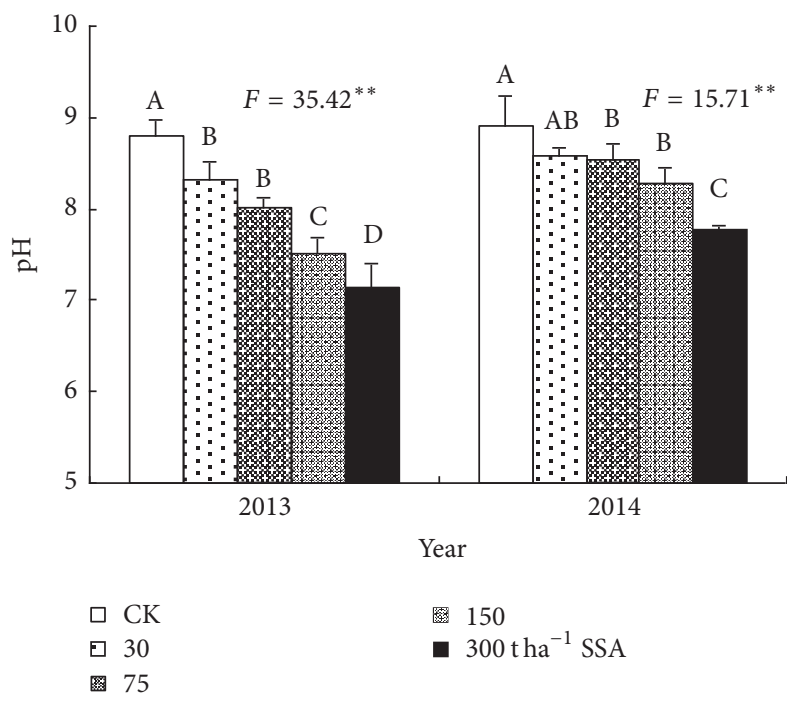

(a)

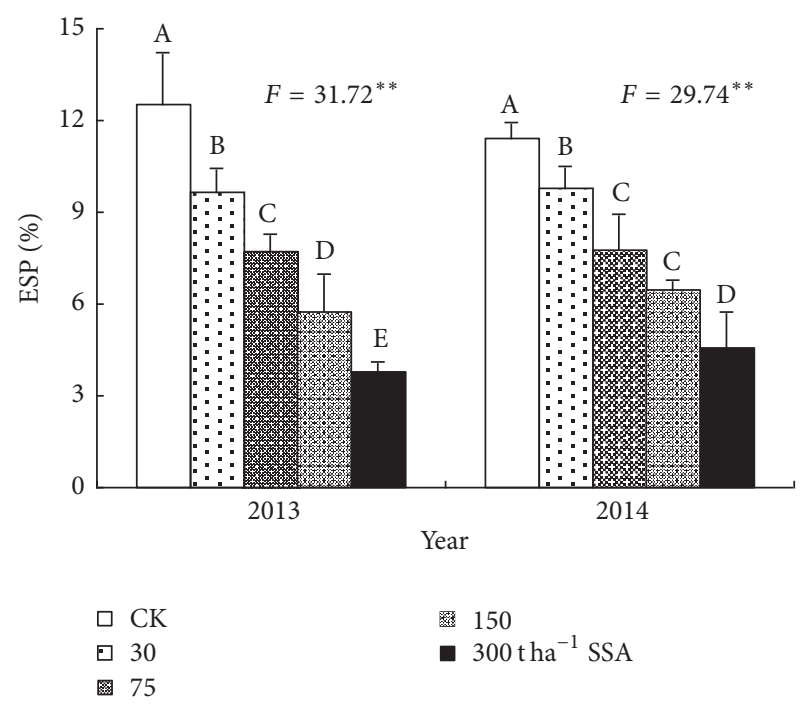

(b)

FIGURE 2: Effects of sewage sludge amendment (SSA) combined with green manuring on pH (a) and ESP (b) of coastal mudflat salt-soil. Vertical bars indicate standard deviations of the means. Columns with different letters show significant difference between sewage sludge amendment rates at $p<0.05$ by LSD's multiple range test. Values of $F$ are the $F$ test in ANOVA; ${ }^{* *} p<0.01$. $\mathrm{pH}$, hydrogen ion concentration; ESP, exchangeable sodium percentage.

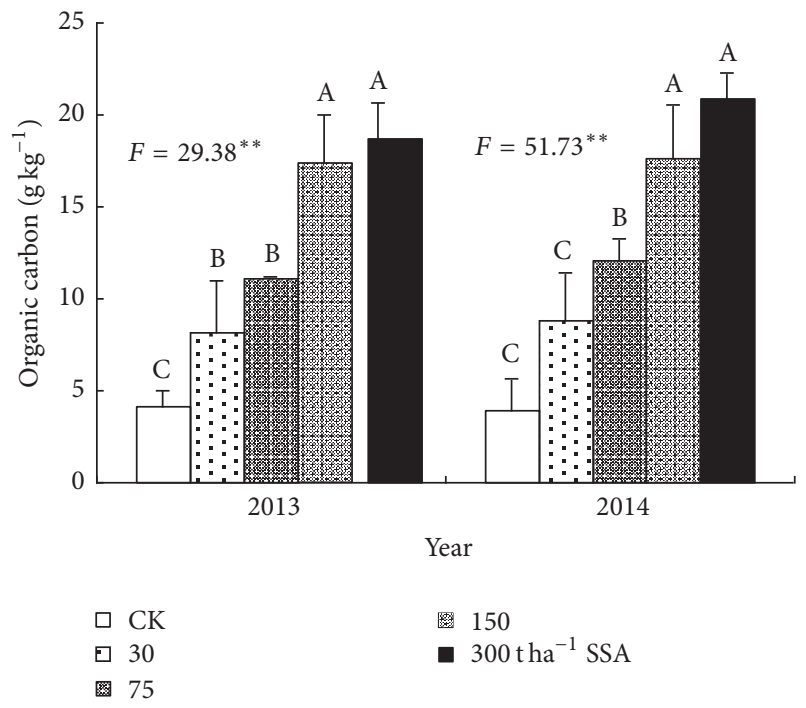

(a)

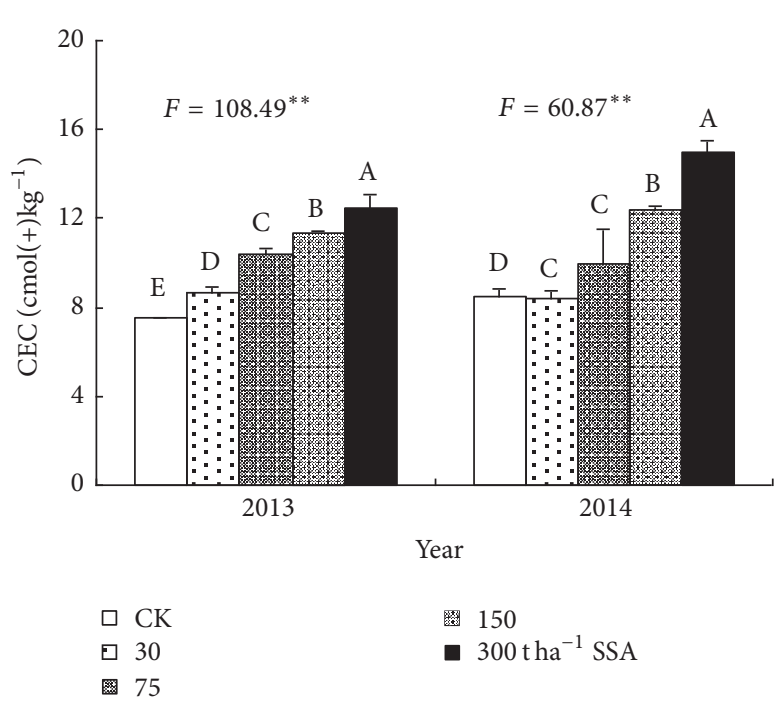

(b)

FIGURE 3: Effects of sewage sludge amendment (SSA) combined with green manuring on organic carbon (a) and CEC (b) of coastal mudflat salt-soil. Vertical bars indicate standard deviations of the means. Columns with different letters show significant difference between sewage sludge amendment rates at $p<0.05$ by LSD's multiple range test. Values of $F$ are the $F$ test in ANOVA; ${ }^{* *} p<0.01$. CEC, cation exchange capacity.

The increments of alkaline $\mathrm{N}$ and available $\mathrm{P}$ in mudflat salt-soil in 2014 were $209.8 \%, 203.4 \%, 402.8 \%$, and $505.8 \%$ and $184.9 \%, 190.1 \%, 239.3 \%$, and $309.6 \%$ at $30,75,150$, and $300 \mathrm{t} \mathrm{ha}^{-1}$ SSA rates, respectively, compared to the control soil.
3.4. Maize Yields. The sewage sludge amendment combined with green manuring significantly increased yields of maize grown in mudflat salt-soil (Figure 5). The maize yield increased by $225.0 \%, 471.1 \%, 546.1 \%$, and $648.7 \%$ at 30,75 , 150 , and $300 \mathrm{t} \mathrm{ha}^{-1}$ SSA rates in 2014, respectively, compared 


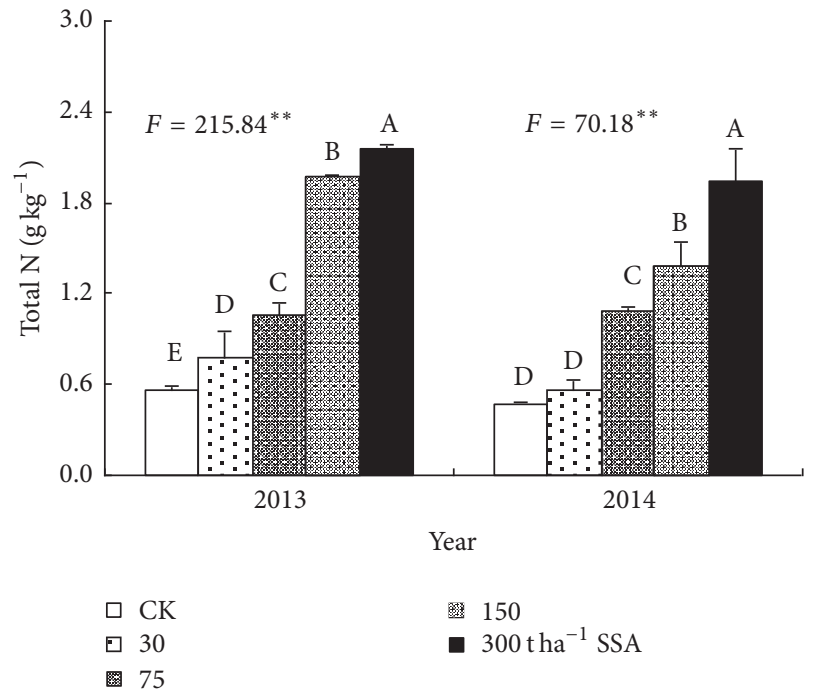

(a)

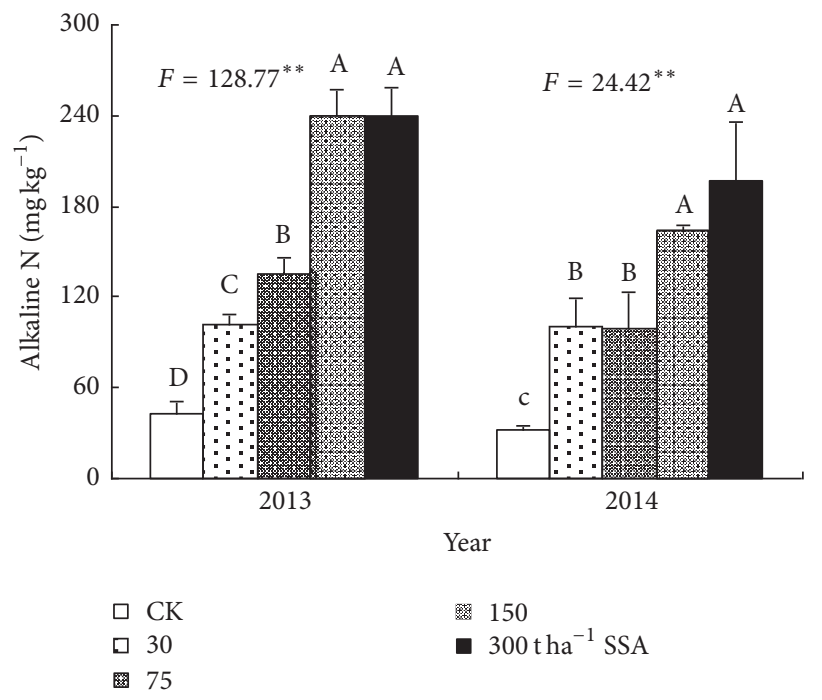

(c)

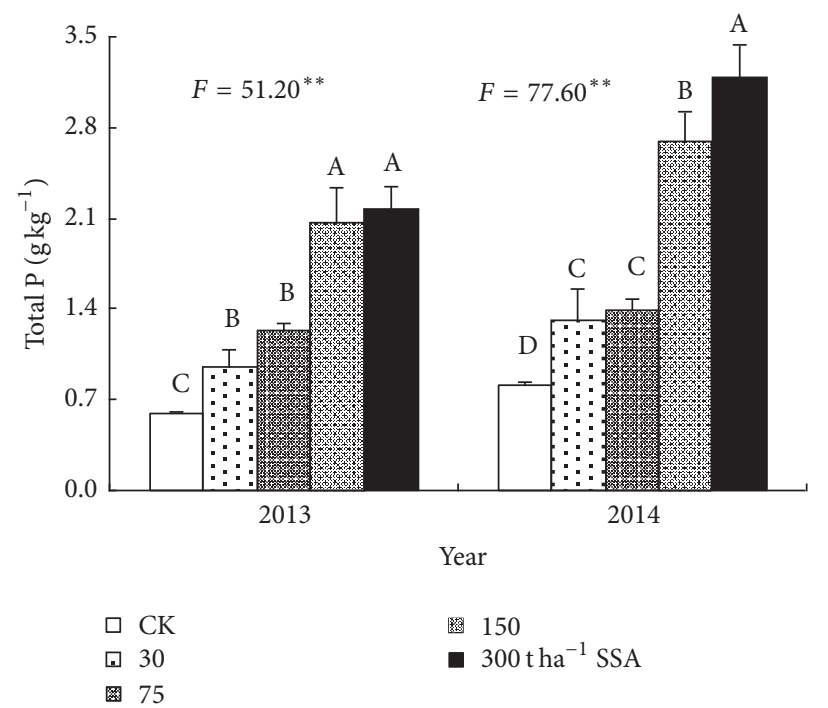

(b)

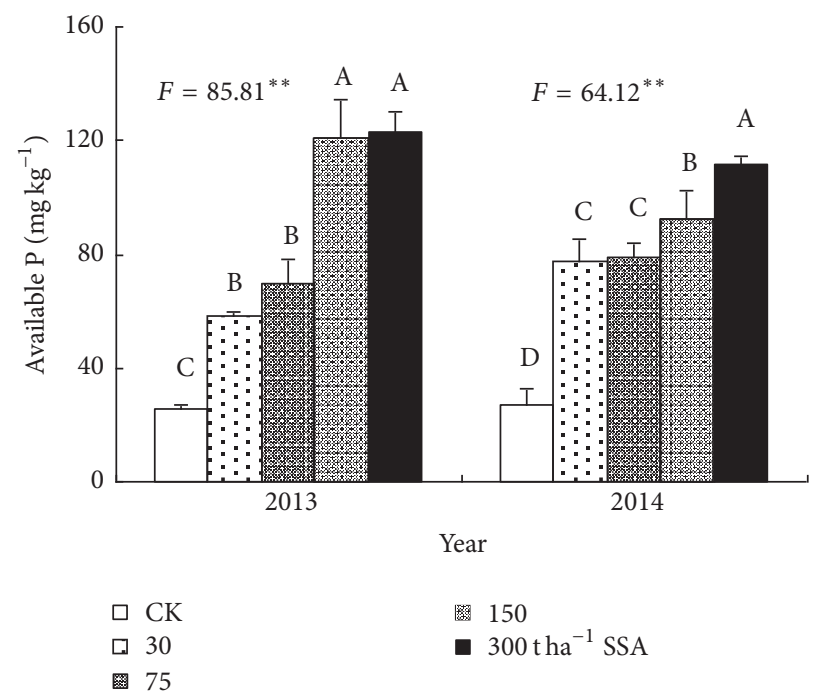

(d)

FIGURE 4: Effects of sewage sludge amendment (SSA) combined with green manuring on the concentration of total N (a), total P (b), alkaline $\mathrm{N}(\mathrm{c})$, and available $\mathrm{P}(\mathrm{d})$ of coastal mudflat salt-soil. Vertical bars indicate standard deviations of the means. Columns with different letters show significant difference between sewage sludge amendment rates at $p<0.05$ by LSD's multiple range test. Values of $F$ are the $F$ test in ANOVA; ${ }^{* *} p<0.01$. N, nitrogen; $\mathrm{P}$, phosphorus.

to the control soil. The similar trend was found in 2013, and the yields of maize at $\geq 75 \mathrm{tha}^{-1}$ SSA rates were significantly higher than that in the control soil.

\section{Discussion}

The sewage sludge amendment combined with green manuring improved physical properties of topsoil in mudflat salt-soil by increasing the percentage of $>0.25 \mathrm{~mm}$ and $0.106-0.25 \mathrm{~mm}$ water-stable aggregates and by decreasing bulk density in $0-20 \mathrm{~cm}$ of the salt-soil layer. The improvement in these physical properties was due to increase in organic carbon content of salt-soil. Soil aggregates are formed from the combination of soil organic matter and soil mineral particles [37]. A significant positive correlation was found between soil organic carbon and the percentage of $>0.25 \mathrm{~mm}$ and $0.106-0.25 \mathrm{~mm}$ water-stable aggregates $(p<$ 0.01) (Figure 6(a)). Release of carbohydrates and organic carbon from biodegradation of OM-rich sludge-amended soil may increase aggregate stability percentage, as it can complex soil organic matter and soil mineral particles to soil aggregate $[38,39]$. The result in the reduction in bulk density by the amendments was not only due to the addition of less dense organic material, but also due to the increase in soil aggregate stability [40] (Figure 6(b)). Previous studies have shown that the application of sewage sludge increased organic carbon in saline and salinized soil [41, 42], subsequently increased aggregate stability in saline-sodic and salinized soil 


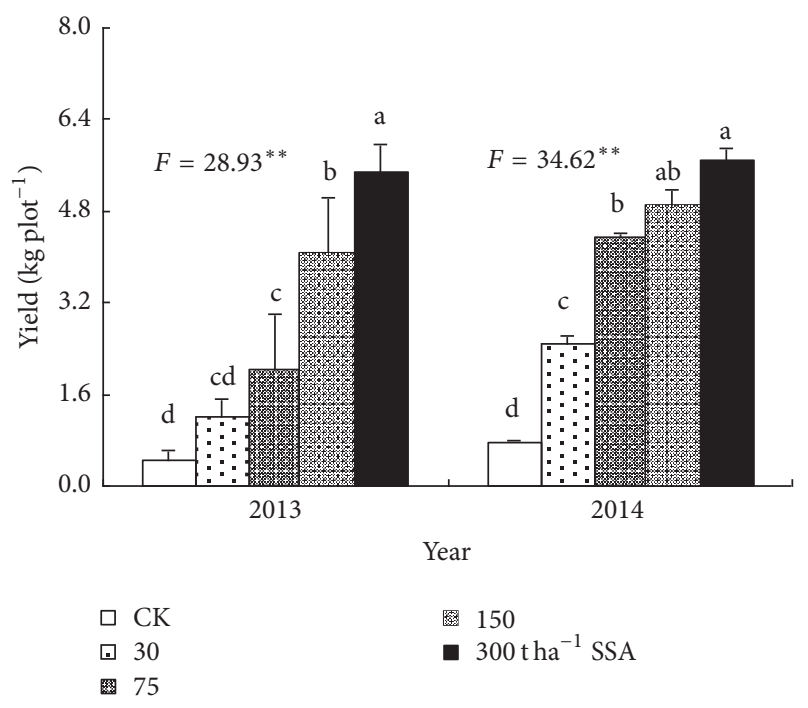

FIGURE 5: Effects of sewage sludge amendment (SSA) combined with green manuring on yield of maize grown in the mudflat salt-soil. Vertical bars indicate standard deviations of the means. Columns with different letters show significant difference between sewage sludge amendment rates at $p<0.05$ by LSD's multiple range test. Values of $F$ are the $F$ test in ANOVA; ${ }^{* *} p<0.01$.

[42, 43], and decreased bulk density in salt-soil and salinized soil $[9,42]$.

Topsoil salinity in mudflat salt-soil decreased as a result of increasing soil aggregate stability and decreasing bulk density. Increase in noncapillary porosity by the increment of soil aggregates stability percentage [8] breaks capillary rise [6] that translocates saline groundwater to topsoil. Guo and Liu [5] also reported that the high salinity in salt-soil is caused by capillary rise that brings saline groundwater to topsoil. In this study, the SSA significantly decreased soil salinity in $0-20 \mathrm{~cm}$ layer, whereas there were no significant changes $(p>0.05)$ in 20-40 cm layer. On the contrary, water-stable aggregates percentage significantly increased in $0-20 \mathrm{~cm}$ layer, whereas there are no significant changes $(p>0.05)$ in $20-40 \mathrm{~cm}$ layer. Statistical analysis showed that a significant negative correlation was found between soil salinity and soil aggregate stability percentage in topsoil and subsurface soil $(p<0.05)$ (Figure 6(c)). The increase in aggregate stability percentage in topsoil acted as a barrier for upward movement of saline groundwater. Thus, soil salinity in $0-20 \mathrm{~cm}$ layer was lower than in $20-40 \mathrm{~cm}$ layer.

The ESP values in mudflat salt-soil decreased with increasing SSA rates. Similar effect was also observed by García-Orenes et al. [42] after the biosolids application to a salinized soil. The decrease in ESP values might be associated with an increase in infiltration rate that enhances soil washing and thus sodium leachability [44]. Moreover, sodium as a micronutrient could be taken up into plant tissue, specially after the three consecutive seasons of green manuring. In addition, a slight dilution effect can be caused by high doses of sewage sludge application and green manure incorporation. In the present study, statistical analysis also showed a significant negative correlation between soil ESP values and soil aggregate stability percentage in topsoil $(p<$ 0.01 ) (Figure 6(d)). The similar negative effects of ESP on soil aggregation were found by other studies [45-47]. This might be attributed to that sodium causes swelling and dispersion of soil mineral particles and slaking of unstable aggregates [45, 48]. In addition, high ESP value can reduce microbial biomass and activity, which may also contribute to the decrease in aggregation [49].

The $\mathrm{pH}$ in mudflat salt-soil decreased with increasing SSA rates, which was similar to our previous studies [9, 20, 21]. Other authors have also found lowering of $\mathrm{pH}$ with SSA [5052]. Intense mineralization of the labile OM pool of sludge treated-soils [53] lowers $\mathrm{pH}$ by releasing humic acid from biodegradation of OM-rich sewage sludge and green manure [50]. In addition, a slight dilution effect could be caused by lower-pH sewage sludge application, especially in treatments with high doses of application.

The sewage sludge amendment combined with green manuring improved salt-soil fertility by increasing CEC and concentration of $\mathrm{N}$ and $\mathrm{P}$ in mudflat salt-soil. Our previous studies also supported the results [9, 20, 21]. In farmland, soil fertility improvement by SSA has also been reported widely $[50,51,54]$. Soil N and P content increased in the mudflat saltsoil amended with sewage sludge due to higher levels of these nutrients in the sewage sludge. Moreover, green manuring, such as Sesbania as a legume, may supply $\mathrm{N}$ through the $\mathrm{N}$ fixation process, thereby increasing $\mathrm{N}$ for soil fertility supply $[55,56]$. The increase in CEC of mudflat soil is probably due to increasing soil OM content $[57,58]$.

Improved physicochemical properties in the mudflat saltsoil enhanced the yields of maize (Zea mays L.) in the mudflat salt-soil. Our previous studies observed the SSA increased biomass of ryegrass (Lolium perenne L.), Sesbania (Sesbania cannabina), and maize (Zea mays L.) [20, 35, 59]. Other studies in farmland also reported that the SSA increased the yields of maize (Zea mays L.) [60], rice (Oryza sativa L.) [61], durum wheat (Triticum durum Desf.) [62], and Spinach (Spinacia oleracea L.) [63]. The yield increase might be the consequence of improved salt-soil physicochemical properties and enriched high-quality OM, N, P, and other nutrients from sewage sludge and green manures.

\section{Conclusions}

The sewage sludge amendment combined with green manuring increased organic carbon in mudflat salt-soil, which improved the physical properties of mudflat salt-soil by increasing aggregate stability of the $0-20 \mathrm{~cm}$ soil layer and decreasing topsoil bulk density. The increase in water-stable aggregate percentage in topsoil acted as a barrier for upward movement of saline groundwater. As a result, soil salinity of the topsoil decreased. The ESP values in mudflat saltsoil decreased with increasing sewage sludge amendment rates. The percentage of water-stable aggregate in mudflat salt-soil showed significantly negative correlation with soil salinity and ESP in mudflat salt-soil $(p<0.01)$. In addition, the sewage sludge amendment combined with green manuring decreased soil $\mathrm{pH}$ and improved soil fertility by 


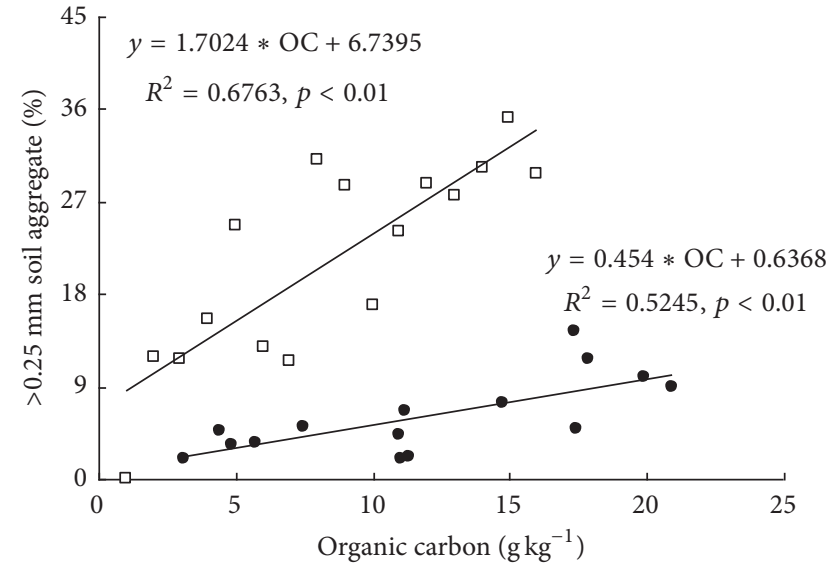

- In 2013

口 In 2014

(a)

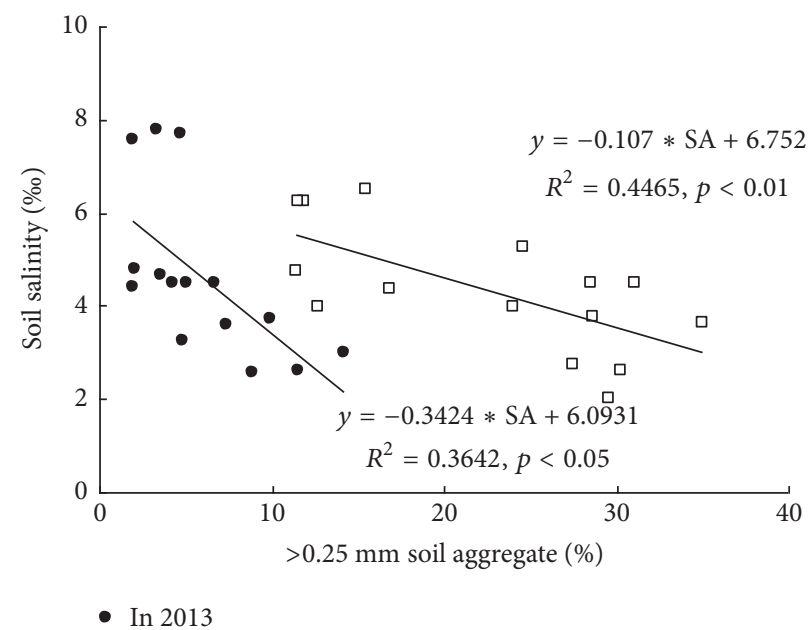

口 In 2014

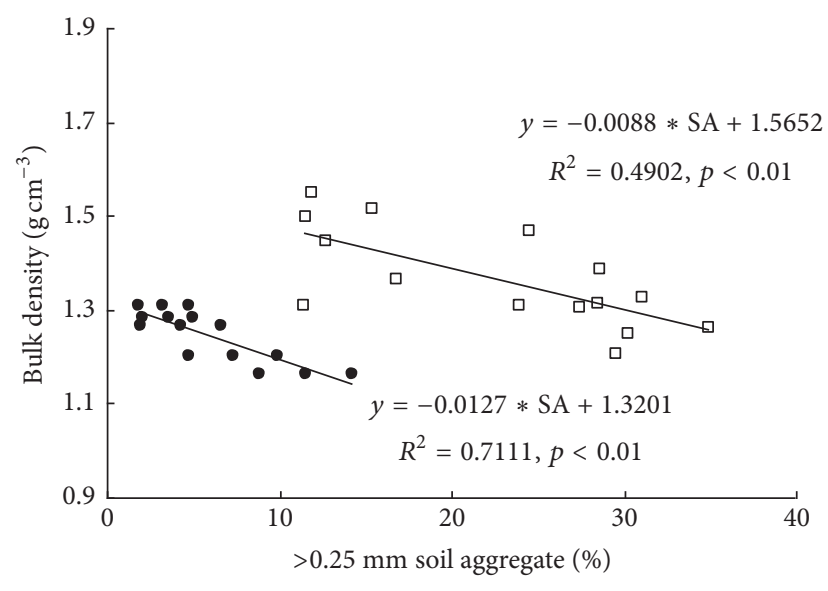

- In 2013

口 In 2014

(b)

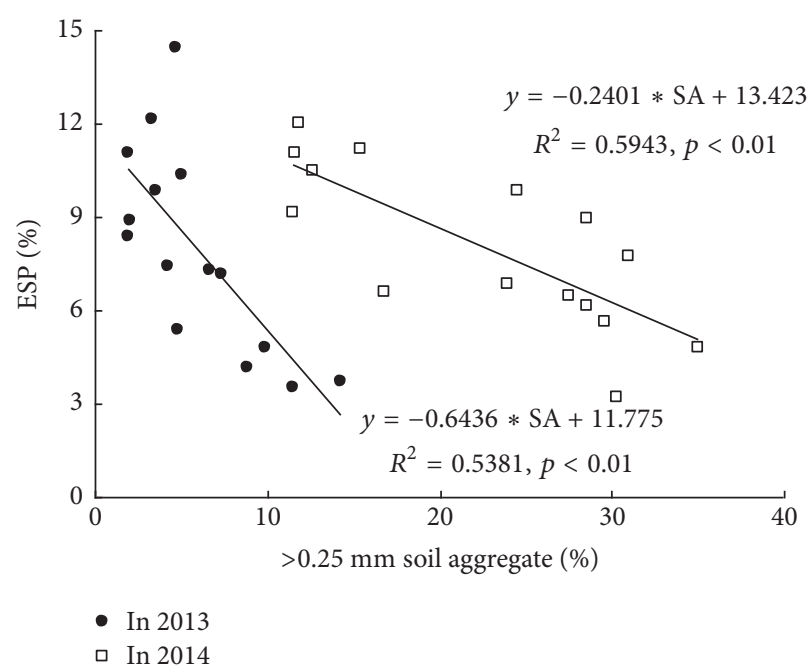

(d)

FIGURE 6: Relationships between percentage of $>0.25 \mathrm{~mm}$ soil water-stable aggregate (SA) and organic carbon (a), bulk density (b), salinity (c), and ESP (d) in the mudflat salt-soil.

increasing CEC and concentration of $\mathrm{N}$ and $\mathrm{P}$ in mudflat saltsoil. The improved physicochemical properties subsequently enhanced the yields of maize (Zea mays L.) in the mudflat salt-soil.

\section{Conflicts of Interest}

The authors declare that there are no conflicts of interest regarding the publication of this paper.

\section{Acknowledgments}

This study is supported by National Natural Science Foundation of China (31101604), Fund for Agricultural Independent Innovation of Jiangsu Province (CX[15]1005), Postdoctoral Science Foundation of China (2016M601755), Fund for Ministry of Science and Technology of China
(2015BAD01B03), Fund for Important Research and Development of Jiangsu Province (BE2015337), Fund for State Key Laboratory of Soil and Sustainable Agriculture (Y412201402), Fund for Three New Agricultural Project of Jiangsu Province (SXGC[2016]277, SXGC[2017]221, and SXGC[2017]222), Fund for Environmental Protection of Yangzhou City (YHK1414), Shuangchuang Talent Plan of Jiangsu Province, China, and Priority Academic Program Development of Jiangsu Higher Education Institutions.

\section{References}

[1] L. L. Wang, X. Y. Sun, S. Y. Li, T. Zhang, W. Zhang, and P. H. Zhai, "Application of organic amendments to a coastal saline soil in North China: effects on soil physical and chemical properties and tree growth," Plos ONE, vol. 9, no. 2, Article ID e89185, 2014. 
[2] W. Cao and M. H. Wong, "Current status of coastal zone issues and management in China: a review," Environment International, vol. 33, no. 7, pp. 985-992, 2007.

[3] Y. Bai, Y. Yan, W. Zuo et al., "Coastal mudflat saline soil amendment by dairy manure and green manuring," International Journal of Agronomy, vol. 2017, Article ID 4635964, 9 pages, 2017.

[4] D. Song, X. H. Wang, X. Zhu, and X. Bao, "Modeling studies of the far-field effects of tidal flat reclamation on tidal dynamics in the East China Seas," Estuarine, Coastal and Shelf Science, vol. 133, pp. 147-160, 2013.

[5] K. Guo and X. Liu, "Dynamics of meltwater quality and quantity during saline ice melting and its effects on the infiltration and desalinization of coastal saline soils," Agricultural Water Management, vol. 139, pp. 1-6, 2014.

[6] M. H. Jorenush and A. R. Sepaskhah, "Modelling capillary rise and soil salinity for shallow saline water table under irrigated and non-irrigated conditions," Agricultural Water Management, vol. 61, no. 2, pp. 125-141, 2003.

[7] R.-J. Yao, J.-S. Yang, T.-J. Zhang et al., "Studies on soil water and salt balances and scenarios simulation using SaltMod in a coastal reclaimed farming area of eastern China," Agricultural Water Management, vol. 131, pp. 115-123, 2014.

[8] C. Xie, Z. Li, Y. Zhang, and Z. Lin, "Principle of relation between organic matter and soil salinity," Soil and Fertilizer, vol. 1, pp. 1922, 1993.

[9] Y. Bai, T. Tao, C. Gu, L. Wang, K. Feng, and Y. Shan, "Mudflat soil amendment by sewage sludge: soil physicochemical properties, perennial ryegrass growth, and metal uptake," Soil Science and Plant Nutrition, vol. 59, no. 6, pp. 942-952, 2013.

[10] Z.-P. Yang, S.-X. Zheng, J. Nie, Y.-L. Liao, and J. Xie, "Effects of long-term winter planted green manure on distribution and storage of organic carbon and nitrogen in water-stable aggregates of reddish paddy soil under a double-rice cropping system," Journal of Integrative Agriculture, vol. 13, no. 8, pp. 1772-1781, 2014.

[11] J. Zhuang, J. F. McCarthy, E. Perfect, L. M. Mayer, and J. D. Jastrow, "Soil water hysteresis in water-stable microaggregates as affected by organic matter," Soil Science Society of America Journal, vol. 72, no. 1, pp. 212-220, 2008.

[12] A. Karami, M. Homaee, S. Afzalinia, H. Ruhipour, and S. Basirat, "Organic resource management: impacts on soil aggregate stability and other soil physico-chemical properties," Agriculture, Ecosystems and Environment, vol. 148, pp. 22-28, 2012.

[13] N. Garcia-Franco, J. Albaladejo, M. Almagro, and M. MartínezMena, "Beneficial effects of reduced tillage and green manure on soil aggregation and stabilization of organic carbon in a Mediterranean agroecosystem," Soil and Tillage Research, vol. 153, pp. 66-75, 2015.

[14] A. R. Barzegar, P. N. Nelson, J. M. Oades, and P. Rengasamy, "Organic matter, sodicity, and clay type: influence on soil aggregation," Soil Science Society of America Journal, vol. 61, no. 4, pp. 1131-1137, 1997.

[15] L. Feng, J. Luo, and Y. Chen, "Dilemma of sewage sludge treatment and disposal in China," Environmental Science and Technology, vol. 49, no. 8, pp. 4781-4782, 2015.

[16] B. Dhir, "Municipal sludge: an effective soil supplement for improving plant growth," Indian Journal of Plant Physiology, vol. 21, no. 2, pp. 213-218, 2016.

[17] R. Y. Surampalli, K. C. K. Lai, S. K. Banerji, J. Smith, R. Y. Tyagi, and B. N. Lohani, "Long-term land application of biosolids-a case study," Water Science and Technology, vol. 57, no. 3, pp. 345352,2008
[18] J. Paz-Ferreiro, G. Gascó, B. Gutiérrez, and A. Méndez, "Soil biochemical activities and the geometric mean of enzyme activities after application of sewage sludge and sewage sludge biochar to soil," Biology and Fertility of Soils, vol. 48, no. 5, pp. 511-517, 2012.

[19] V. G. Franco-Otero, P. Soler-Rovira, D. Hernández, E. G. Lópezde-Sá, and C. Plaza, "Short-term effects of organic municipal wastes on wheat yield, microbial biomass, microbial activity, and chemical properties of soil," Biology and Fertility of Soils, vol. 48, no. 2, pp. 205-216, 2012.

[20] Y. Bai, C. Zang, M. Gu et al., "Sewage sludge as an initial fertility driver for rapid improvement of mudflat salt-soils," Science of the Total Environment, vol. 578, pp. 47-55, 2017.

[21] Y. Bai, C. Gu, T. Tao, L. Wang, K. Feng, and Y. Shan, "Growth characteristics, nutrient uptake, and metal accumulation of ryegrass (Lolium perenne L.) in sludge-amended mudflats," Acta Agriculturae Scandinavica Section B: Soil and Plant Science, vol. 63, no. 4, pp. 352-359, 2013.

[22] H. Chen, S. Yan, Z. Ye, H. Meng, and Y. Zhu, "Utilization of urban sewage sludge: chinese perspectives," Environmental Science and Pollution Research, vol. 19, no. 5, pp. 1454-1463, 2012.

[23] A. Pathak, M. G. Dastidar, and T. R. Sreekrishnan, "Bioleaching of heavy metals from sewage sludge: a review," Journal of Environmental Management, vol. 90, no. 8, pp. 2343-2353, 2009.

[24] T. O. Fabunmi, M. U. Agbonlahor, J. N. Odedina, and S. O. Adigbo, "Profitability of pre-season green manure practices using maize as a test crop in a derived savanna of Nigeria," Pakistan Journal of Agricultural Sciences, vol. 49, no. 4, pp. 593596, 2012.

[25] C. D. S. B. Bonini and M. C. Alves, "Aggregate stability of a degraded Oxisol in recovery with green manure, lime and gypsum," Revista Brasileira de Ciência do Solo, vol. 35, no. 4, pp. 1263-1270, 2011.

[26] L. Talgre, E. Lauringson, H. Roostalu, A. Astover, and A. Makke, "Green manure as a nutrient source for succeeding crops," Plant, Soil and Environment, vol. 58, no. 6, pp. 275-281, 2012.

[27] C. D. S. B. Bonini and M. C. Alves, "Recovery of soil physical properties by green manure, liming, gypsum and pasture and spontaneous native species," Revista Brasileira de Ciência do Solo, vol. 35, no. 4, pp. 1397-1406, 2011.

[28] J. R. T. Martens and M. H. Entz, "Integrating green manure and grazing systems: a review," Canadian Journal of Plant Science, vol. 91, no. 5, pp. 811-824, 2011.

[29] M. Zubair, F. Anwar, M. Ashraf, A. Ashraf, and S. A. S. Chatha, "Effect of green and farmyard manure on carbohydrates dynamics of salt-affected soil," Journal of Soil Science and Plant Nutrition, vol. 12, no. 3, pp. 497-510, 2012.

[30] B. Bruning, R. van Logtestijn, R. Broekman, A. de Vos, A. P. González, and J. Rozema, "Growth and nitrogen fixation of legumes at increased salinity under field conditions: implications for the use of green manures in saline environments," $A o B$ PLANTS, vol. 7, no. 1, 2015.

[31] V. S. Thomaidi, A. S. Stasinakis, V. L. Borova, and N. S. Thomaidis, "Assessing the risk associated with the presence of emerging organic contaminants in sludge-amended soil: a country-level analysis," Science of the Total Environment, vol. 548-549, pp. 280-288, 2016.

[32] O. Sortino, E. Montoneri, C. Patanè, R. Rosato, S. Tabasso, and $\mathrm{M}$. Ginepro, "Benefits for agriculture and the environment from urban waste," Science of the Total Environment, vol. 487, no. 1, pp. 443-451, 2014. 
[33] S. Schulz, J. D. H. Keatinge, and G. J. Wells, "Productivity and residual effects of legumes in rice-based cropping systems in a warm-temperate environment: I. Legume biomass production and N fixation," Field Crops Research, vol. 61, no. 1, pp. 23-35, 1999.

[34] B. K. Northup and S. C. Rao, "Effects of legume green manures on forage produced in continuous wheat systems," Agronomy Journal, vol. 108, no. 1, pp. 101-108, 2016.

[35] Y.-C. Bai, W.-G. Zuo, H.-T. Zhao et al., "Distribution of heavy metals in maize and mudflat saline soil amended by sewage sludge," Journal of Soils and Sediments, vol. 17, no. 6, pp. 15651578, 2017.

[36] S. Bao, Soil and Agro-Chemistry Analysis, China Agricultural Press, Beijing, China, 3rd edition, 2000.

[37] J. M. Tisdall and J. M. Oades, "Organic matter and water-stable aggregates in soils," Journal of Soil Science, vol. 33, no. 2, pp. 141$163,1982$.

[38] A. Lax and F. García-Orenes, "Carbohydrates of municipal solid wastes as aggregation factor of soils," Soil Technology, vol. 6, no. 2, pp. 157-162, 1993.

[39] M. V. Cheshire, G. P. Sparling, and C. M. Mundie, "Effect of periodate treatment of soil on carbohydrate constituents and soil aggregation," Journal of Soil Science, vol. 34, no. 1, pp. 105112, 1983.

[40] C. E. Clapp, S. A. Stark, D. E. Clay, and W. E. Larson, "Sewage sludge organic matter and soil properties," in The Role of Organic Matter in Modern Agriculture, Y. Chen and Y. Avnimelech, Eds., Martinus Nijhoff Publishers, Dordrecht, the Netherlands, 1986.

[41] A. Lakhdar, R. Scelza, R. Scotti et al., "The effect of compost and sewage sludge on soil biologic activities in salt affected soil," Revista de la Ciencia del Suelo y Nutricion Vegetal, vol. 10, no. 1, pp. 40-47, 2010.

[42] F. García-Orenes, C. Guerrero, J. Mataix-Solera, J. NavarroPedreño, I. Gómez, and J. Mataix-Beneyto, "Factors controlling the aggregate stability and bulk density in two different degraded soils amended with biosolids," Soil and Tillage Research, vol. 82, no. 1, pp. 65-76, 2005.

[43] I. Angin, E. L. Aksakal, T. Oztas, and A. Hanay, "Effects of municipal solid waste compost (MSWC) application on certain physical properties of soils subjected to freeze-thaw," Soil and Tillage Research, vol. 130, pp. 58-61, 2013.

[44] A. Lax, E. Diaz, V. Castillo, and J. Albaladejo, "Reclamation of physical and chemical properties of a salinized soil by organic amendment," Arid Soil Research and Rehabilitation, vol. 8, no. 1, pp. 9-17, 1994.

[45] G. Crescimanno, M. Iovino, and G. Provenzano, "Influence of salinity and sodicity on soil structural and hydraulic characteristics," Soil Science Society of America Journal, vol. 59, no. 6, pp. 1701-1708, 1995.

[46] I. Shainberg, G. J. Levy, P. Rengasamy, and H. Frenkel, "Aggregate stability and seal formation as affected by drops' impact energy and soil amendments," Soil Science, vol. 154, no. 2, pp. 113-119, 1992.

[47] T. M. Abu-Sharar, F. T. Bingham, and J. D. Rhoades, "Stability of soil aggregates as affected by electrolyte concentration and composition," Soil Science Society of America Journal, vol. 51, no. 2, pp. 309-314, 1987.

[48] F. Hu, H. Li, X. Liu et al., "Quantitative characterization of nonclassic polarization of cations on clay aggregate stability," PLoS ONE, vol. 10, no. 4, Article ID e0122460, 2015.
[49] D. N. Rietz and R. J. Haynes, "Effects of irrigation-induced salinity and sodicity on soil microbial activity," Soil Biology \& Biochemistry, vol. 35, no. 6, pp. 845-854, 2003.

[50] J. L. Moreno, C. García, T. Hernández, and M. Ayuso, "Application of composted sewage sludges contaminated with heavy metals to an agricultural soil: effect on lettuce growth," Soil Science and Plant Nutrition, vol. 43, no. 3, pp. 565-573, 1997.

[51] R. P. Singh and M. Agrawal, "Effects of sewage sludge amendment on heavy metal accumulation and consequent responses of Beta vulgaris plants," Chemosphere, vol. 67, no. 11, pp. 22292240, 2007.

[52] R. P. Singh and M. Agrawal, "Effect of different sewage sludge applications on growth and yield of Vigna radiata L. field crop: metal uptake by plant," Ecological Engineering, vol. 36, no. 7, pp. 969-972, 2010.

[53] S. Torri, R. Alvarez, and R. Lavado, "Mineralization of carbon from sewage sludge in three soils of the Argentine pampas," Communications in Soil Science and Plant Analysis, vol. 34, no. 13-14, pp. 2035-2043, 2003.

[54] X. Wang, T. Chen, Y. Ge, and Y. Jia, "Studies on land application of sewage sludge and its limiting factors," Journal of Hazardous Materials, vol. 160, no. 2-3, pp. 554-558, 2008.

[55] L. O. Brandsæter, H. Heggen, H. Riley, E. Stubhaug, and T. M. Henriksen, "Winter survival, biomass accumulation and $\mathrm{N}$ mineralization of winter annual and biennial legumes sown at various times of year in Northern Temperate Regions," European Journal of Agronomy, vol. 28, no. 3, pp. 437-448, 2008.

[56] Z. Xie, S. Tu, F. Shah et al., "Substitution of fertilizer-N by green manure improves the sustainability of yield in double-rice cropping system in south China," Field Crops Research, vol. 188, pp. 142-149, 2016.

[57] K. Chaney and R. S. Swift, "The influence of organic matter on aggregate stability in some British soils," Journal of Soil Science, vol. 35, no. 2, pp. 223-230, 1984.

[58] S. Goldberg, D. L. Suarez, and R. A. Glaubig, "Factors affecting clay dispersion and aggregate stability of arid-zone soils," Soil Science, vol. 146, no. 5, pp. 317-325, 1988.

[59] Y.-C. Bai, C.-H. Gu, T.-Y. Tao et al., "Responses of ryegrass (Lolium perenne L.) grown in mudflats to sewage sludge amendment," Journal of Integrative Agriculture, vol. 13, no. 2, pp. 426433, 2014.

[60] M. K. Jamali, T. G. Kazi, M. B. Arain et al., "Use of sewage sludge after liming as fertilizer for maize growth," Pedosphere, vol. 18, no. 2, pp. 203-213, 2008.

[61] R. P. Singh and M. Agrawal, "Variations in heavy metal accumulation, growth and yield of rice plants grown at different sewage sludge amendment rates," Ecotoxicology and Environmental Safety, vol. 73, no. 4, pp. 632-641, 2010.

[62] L. Tamrabet, H. Bouzerzour, M. Kribaa, and M. Makhlouf, "The effect of sewage sludge application on durum wheat (Triticum durum)," International Journal of Agriculture and Biology, vol. 11, no. 6, pp. 741-745, 2009.

[63] V. M. Ngole, "Variations in sludge effects on selected properties of four soil types and vegetable yield," African Journal of Agricultural Research, vol. 5, no. 23, pp. 3279-3290, 2010. 


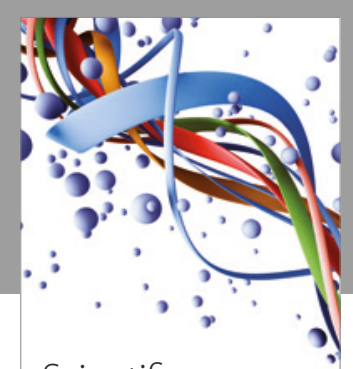

Scientifica
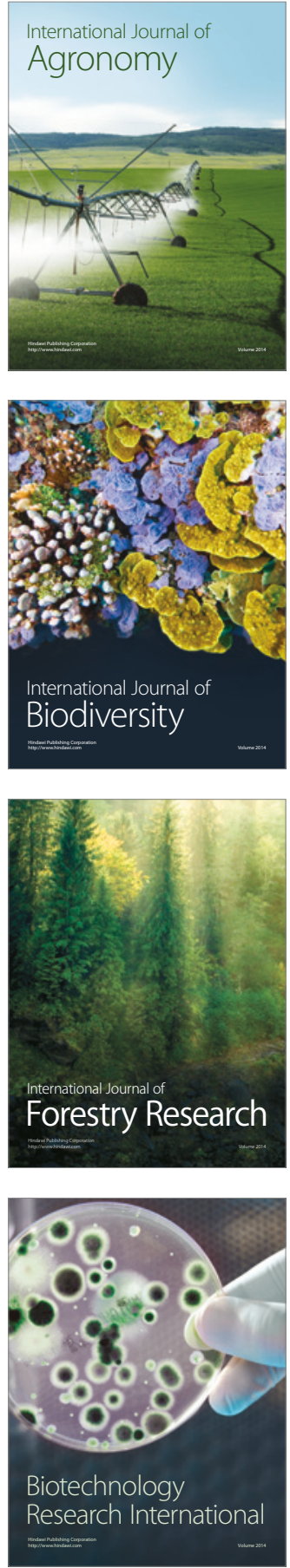
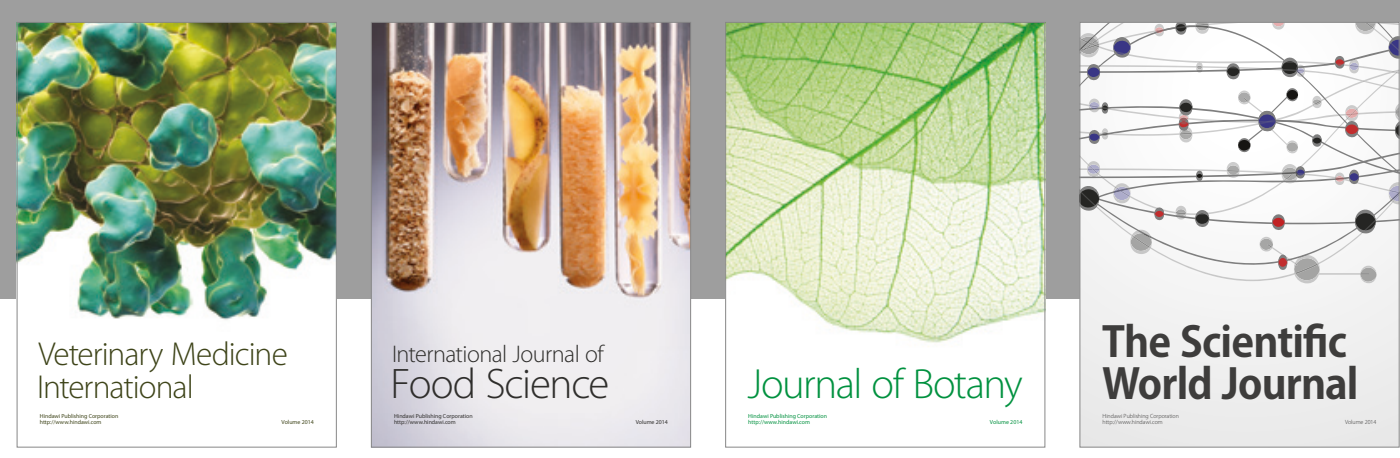

The Scientific

\section{World Journal}

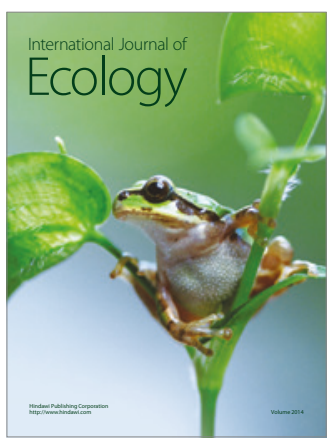

\section{Hindawi}

Submit your manuscripts at

https://www.hindawi.com
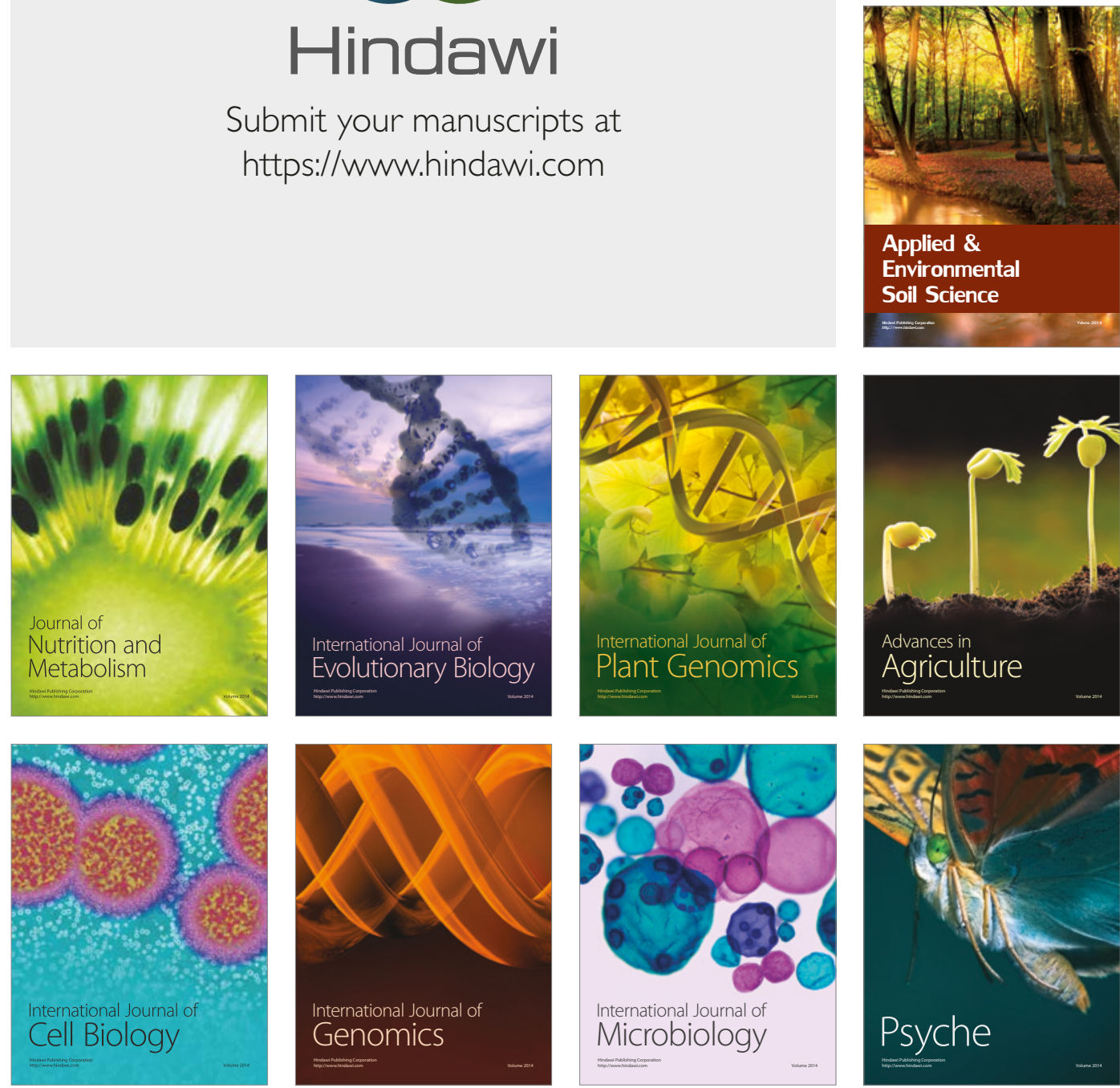

hternational Journal of Microbiology
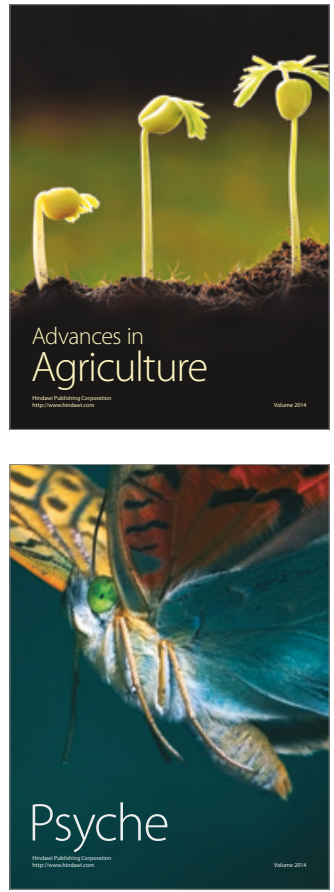